\title{
Association studies of several cholesterol-related genes (ABCA1, CETP and LIPC) with serum lipids and risk of Alzheimer's disease
}

\author{
Zhijie Xiao ${ }^{1}$, Juan Wang ${ }^{1 *}$, Weirong Chen ${ }^{2}$, Peng Wang ${ }^{1}$, Houlin Zeng ${ }^{2}$ and Weixi Chen ${ }^{2}$
}

\begin{abstract}
Objectives: Accumulating evidence suggested that dysregulation of cholesterol homeostasis might be a major etiologic factor in initiating and promoting neurodegeneration in Alzheimer's disease (AD). ATP-binding cassette transporter $\mathrm{A} 1$ (ABCA1), hepatic lipase (HL, coding genes named LIPC) and cholesteryl ester transfer protein (CETP) are important components of high-density lipoprotein (HDL) metabolism and reverse cholesterol transport (RCT) implicated in atherosclerosis and neurodegenerative diseases. In the present study, we will investigate the possible association of several common polymorphisms (ABCA1R219K, CETPTaqIB and LIPC-250 G/A) with susceptibility to $\mathrm{AD}$ and plasma lipid levels.

Methods: Case-control study of 208 Han Chinese (104 AD patients and 104 non-demented controls) from Changsha area in Hunan Province was performed using the PCR-RFLP analysis. Cognitive decline was assessed using Mini Mental State Examination (MMSE) as a standardized method. Additionally, fasting lipid profile and the cognitive testing scores including Wechsler Memory Scale (WMS) and Wisconsin Card Sorting Test (WCST) were recorded.

Results and conclusions: We found significant differences among the genotype distributions of these three genes in $\mathrm{AD}$ patients when compared with controls. But after adjusting other factors, multivariate logistic regression analysis showed only ABCA1R219K ( $\mathrm{B}=-0.903, P=0.005, \mathrm{OR}=0.405,95 \% \mathrm{Cl}: 0.217-0.758$ ) and LIPC-250 G/A variants ( $B=-0.905, P=0.018, O R=0.405,95 \% C l: 0.191-0.858)$ were associated with decreased $A D$ risk. There were significantly higher levels of high-density lipoprotein cholesterol $(\mathrm{HDL}-\mathrm{C})$ and apolipoproteinA-I in the carriers of KK genotype and $\mathrm{K}$ allele $(P<0.05)$, and B2B2 genotype of CETP Taq1B showed significant association with higher HDL-C levels than other genotypes ( $F=5.598, P=0.004)$, while $-250 \mathrm{G} / \mathrm{A}$ polymorphisms had no significant effect on HDL-C. In total population, subjects carrying ABCA1219K allele or LIPC-250A allele obtained higher MMSE or WMS scores than non-carriers, however, no significant association was observed in AD group or controls. Therefore, this preliminary study showed that the gene variants of ABCA1R219K and LIPC-250 G/A might influence AD susceptibility in South Chinese Han population, but the polymorphism of CETPTaq1B didn't show any association in despite of being a significant determinant of $\mathrm{HDL}-\mathrm{C}$.
\end{abstract}

Keywords: Alzheimer's disease, Lipids, ATP-binding cassette transporter A1, LIPC, Cholesteryl ester transfer protein, Single-nucleotide polymorphisms

\footnotetext{
* Correspondence: wangjuan0495@126.com

'Department of Neurology, The Second XiangYa Hospital of Central South University, No.139 of People's Middle Road, Changsha, Hunan Province 410011, People's Republic of China

Full list of author information is available at the end of the article
} 


\section{Introduction}

Alzheimer' disease(AD) is one of the most common neurodegenerative diseases which hallmark is the deposition of amyloid- $\beta(A \beta)$ in brain parenchyma and cerebral blood vessels, accompanied by progressive cognitive decline. However, detailed pathogentic mechanisms of AD remain a matter of speculation. With the exception of age and APOE\&4 allele which is only one undisputed genetic component identified [1,2], environmental risk profiles including smoking, alcohol, obesity, hypertension, dislipidemia, diabetes and cardiovascular diseases may be candidates for AD [3-5]. Previous research has demonstrated that cerebral atherosclerosis was strongly associated with an increased frequency of neuritic plaques [6]. Moreover, the association of some gene variation in lipid metabolism with $\mathrm{AD}$ has been identified in a number of study $[7,8]$. So the close links between vascular pathology and AD have been payed more attention.

Accumulated evidence has shown that dysfunction of cholesterol metabolism may contribute to cognitive decline and AD [9], such as decreased high-density lipoprotein cholesterol (HDL-C) levels [10,11], increased lowdensity lipoprotein cholesterol (LDL-C) levels $[4,12]$, and decreased apolipoproteinA-I (apoA-I) levels [11,13] known to be important risk factors for coronary atherosclerosis disease (CAD). The recent identification has been extensively recognized that the effect of serum total cholesterol (TC) on dementia risk occurs in midlife but not late-life, which may be different cardiovascular risk factor profiles for $\mathrm{AD}[14,15]$. In addition, intervention of cholesterol-lowering drugs in some observational or cohort studies may decrease risk of developing dementia [16] and delay the onset of AD in cognitively healthy elderly individuals [17]. Growing evidence in previous animal and cellular studies has also suggested that abnormalities in cholesterol metabolism are important in the pathogenesis of $\mathrm{AD}$, potentially by increasing neuronal content of cholesterol, cleavage of the amyloid protein precursor (APP), accumulation of $A \beta$ peptide, neuroinflammation, impairment in the cholinergic system and working memory [18-20]. However, the mechanisms are still ill-defined. Recent work from Ghribi $\mathrm{O}$ and Marwarha $\mathrm{G}$ et al. indicated that the oxidized cholesterol metabolite, 27-hydroxycholesterol, which had the ability to cross into the brain, could increase $A \beta$ levels and phosphorylated tau-protein in adult rabbit brain slices [21,22], and the same result also observed in cultured human neuroblastoma SH-SY5Y cells [23]. Sharma $S$ et al. found that hypercholesterolemiainduced $A \beta$ production in rabbit brain was associated with alteration in IGF-1 signaling [24].

Many regulating genes affecting cholesterol or lipoprotein function have been implicated in the pathogenesis of atherosclerosis diseases, especially reverse cholesterol transport (RCT) mediated by HDL-C. HDL biogenesis occurs through intergrated pathway that involves the lipid transporter $A B C A 1$ interacting with lipid-free apoA-I in the initial steps, cholesteryl-ester transfer protein (CETP) transferring cholesteryl-esters to VLDL/LDL by the LDL receptor for eventual catabolism, lipoprotein lipase, hepatic lipase, and endothelial lipase contributing to the hydrolysis of phospholipids and residual triglycerides, and phospholipid transfer protein transferring phospholipids from VLDL/LDL to HDL, etc. [25]. ABCA1 is a transmembrane protein responsible for the efflux of cholesterol and phospholipids to apolipoproteins such as apoA-I and apoE [26], the gene mutations of which has been recognized contributing to Tangier's disease and familial hypoalphalipoproteinemia [27]. As known as common polymorphisms in this gene could affect plasma HDL-C levels and the risk of atherosclerosis and CAD [28-30], dysregulation of ABCA1 expression may be a central mediator of $\mathrm{AD}$ neuropathology and dementia severity [31]. Several studies with AD mouse model revealed that ABCA1 expression could regulate the level of apoE lipidation and the production of $\mathrm{A} \beta$ [32-35]. But controversies still remained [36,37]. One of the most studied ABCA1 variants is R219K (rs2230806) in exon region. Previous researches indicated the common R219K variant was associated with CSF cholesterol levels [38].

Hepatic lipase (HL) is a lipolytic enzyme, synthesized by hepatocytes, not only participating in hydrolysis of triglycerides and phospholipids of plasma HDL and LDL, resulting in the formation of atherogenic small dense $\mathrm{LDL}$ and $\mathrm{HDL}_{3}-\mathrm{C}$ particles [39], but also playing an important role in RCT by its ability in the cellular uptake of remnant lipoproteins as a ligand in the liver [40]. CETP is a plasma glycoprotein that facilitates the transferring of cholesterol esters, triglycerides and phospholipids between plasma lipoproteins [41]. Common genetic variants at both the CETP and LIPC loci have been identified that may cause significant alterations in HDL-C level and atherosclerosis, however, the findings are still controversial in diverse racial groups [42-45]. The HL gene is located on chromosome 15 (q15-q22) in humans [46]. Four common LIPC promoter variants (-250 G/A, $-514 \mathrm{C} / \mathrm{T},-710 \mathrm{~T} / \mathrm{C}$ and $-763 \mathrm{~A} / \mathrm{G})$ which are in almost complete linkage disequilibrium have been widely studied [47]. The rare $-250 \mathrm{~A}$ and $-514 \mathrm{~T}$ alleles have been associated with low HL activity [48,49], buoyant LDL particles [49], high triglyceride levels [50], high HDL-C levels, and decreased risk of CAD [50-52]. One of the most identified CETP variant is the TaqIB (rs708272) in the first CETP intron [53]. The minor "B2" allele (absence of the TaqIB restriction site) has been associated with increased HDL-C levels and decreased CETP activity [44].

As mentioned, abnormal lipid metabolism was consistently indicated in the pathogenesis of $\mathrm{AD}$, thereby, such 
genetic variants may provide important functional candidates for $\mathrm{AD}$. In the past decade, the relationship between ABCA1R219K variants and risk of $A D$ have been reported in different regions and ethnic groups, however, conflicting results were noted [38,54-58]. Polymorphisms in the CETP gene have been associated with lower cardiovascular risk, but associations with memory decline and dementia risk are unclear. Chen DW et al. in Xuanwu Hospital of our country showed that there was no significant difference of CETPTaq1B polymorphism between $\mathrm{AD}$ and control groups regardless of APOE $\varepsilon 4$ carrier status [59]. It also has been reported about the association between several LIPC SNPs with the risk of $\mathrm{AD}$ in two research $[60,61]$, however, no significant difference was identified. Previously inconsistent results have appeared in the literature, hence, the epistatic effect of such variants on the risk profile associated with $\mathrm{AD}$ remains to be elucidated.

Accordingly, in this study we will determine the relationship of polymorphisms in several common HDL-Crelated gene loci (ABCA1R219K, LIPC-250 G/A and CETP Taq1B) with plasma lipids and the risk of AD in Southern Chinese Han population.

\section{Material and methods Subjects}

A total of 104 clinically diagnosed late-onset AD patients and 104 controls without cognitive impairment were randomly collected from a population of Chinese Han nationality in Changsha area. Mini-mental state examination (MMSE) was used as the measure of cognitive detecting and dementia severity [62]. All cases were sporadic AD patients without relationships in Chinese Han population of Hunan Province. Nobody had a family history of dementia. All patients were clinically evaluated and met the NINCDS/ADRDA criteria for diagnosed probable $\mathrm{AD}$ [63]. There were 57 men and 47 women in $\mathrm{AD}$ subjects, with an average age of $77.8 \pm 6.74$ years and an average age-at-onset of $72.9 \pm 7.29$ years. During the same period, all controls were recruited from old people above 65 years in the same region, without cognitive impairment and any severe nervous system diseases and mental illnesses. There were 56 men and 48 women. The mean age was $76.5 \pm 6.14$ years. Basic physical examination, Wechsler Memory Scale Test and Wisconsin Cart Sorting Test were carried out for the whole subjects. Everyone was interviewed for a detailed inquiry including medical history, including family history, education, smoke, alcohol, hyperlipidemia, hypertension, diabetes and coronary heart disease, etc. A venous fasting blood sample of $5 \mathrm{ml}$ was obtained from all subjects. The present study was carried out in compliance with the Helsinki Declaration and was approved by the Ethics Committee of the Second
XiangYa Hospital of Central South University. Written informed consent was obtained from the patient for publication of this report and any accompanying images.

\section{Biochemical analysis}

$3 \mathrm{ml}$ blood sample was used to determine serum lipid levels. The levels of TC, TG, HDL-C, and LDL-C in samples were determined by enzymatic methods, and serum apoA-I and apoB levels by the immunoturbidimetric immunoassay. All determinations were performed with an autoanalyzer in the Clinical Laboratory Center of the Second XiangYa Hospital of Central South University. According to NCEP-Adult Treatment Panel III [64], lipid parameters of all subjects were stratified presenting with appropriate HDL-C level $(\geq 1.03 \mathrm{mmol} / \mathrm{L}$ [40 mg/dL]) or low HDL-C (<1.03 mmol/L); appropriate TC level $(\leq 5.17 \mathrm{mmol} / \mathrm{L}[200 \mathrm{mg} / \mathrm{dL}])$ or higher level ( $>5.17 \mathrm{mmol} / \mathrm{L})$; appropriate TG level $(\leq 1.70 \mathrm{mmol} / \mathrm{L}$ [150 mg/dL]) or higher level (>1.70 mmol/L); appropriate LDL-C level $(\leq 2.59 \mathrm{mmol} / \mathrm{L}[100 \mathrm{mg} / \mathrm{dL}])$ or higher level $(>2.59 \mathrm{mmol} / \mathrm{L})$.

\section{Genotying}

The remaining $2 \mathrm{ml}$ blood sample was used to extract genomic DNA by phenol-chloroform methods. The isolated DNA was stored at $4^{\circ} \mathrm{C}$ until analysis. All genotypes had been examined using restriction fragment length polymorphism (RFLP) amplified by polymerase chain reaction (PCR). Information on polymorphic sites of ABCA1, LIPC and CETP was from the database of single nucleotide polymorphisms (SNPs) established by the National Center for Biotechnology Information. The ABCA1 R219K polymorphism was investigated by using the following primers: 5'-GTA TTT TTG CAA GGC TAC CAG TTA CAT TTG ACAA-3'(forward) and 5'-GAT TGG CTT CAG GAT GTCC-3'(reverse), according to previous literure [65]. The detection of genotypes was performed using $8 \%$ polyacrylamide gel electrophoresis. The SNP rs2230806 predicts a nonsynonymous $\mathrm{G}$ to A exchange in exon 7 of ABCA1 gene resulting in a $\mathrm{R}$ (Arg) to $\mathrm{K}$ (Lys) amino acid exchange at position219. After digestion with EcoNI, three different fragments: $177 \mathrm{bp}$ or $107,70 \mathrm{bp}$ were generated. For the LIPC-250 G/A and CETP Taq1B polymorphisms, PCR amplification was performed using 5'-GGCAAGGGCAT CTTTGCTTC-3'(forward)/ 5'-GGTCGATTTACAGAAG TGCTTC-3'(reverse) [66] and 5'-CACTAGCCCAGAG AGAGGAGTGCC-3'(forward)/5'-CTGAGCCCAGCCGC ACACTAA-3'(reverse) [67], respectively. The LIPC-250 G/ A products were 411, 301 and 110 bp or 301 and 110 bp or 411 bp by restriction enzyme DraI. The PCR amplification of CETP Taq1B was catalyzed by TaqI to generate 535 bp, 
$361 \mathrm{bp}$ and $174 \mathrm{bp}$ or $361 \mathrm{bp}$ and $174 \mathrm{bp}$ or $535 \mathrm{bp}$ (Figures 1, 2, 3).

\section{Statistical analyses}

Quantitative variables were expressed as mean \pm standard deviation, and qualitative variables as percentages. First, quantitative data was performed for normality test, if not, transformed into natural logarithm profile. The comparison of quantitative traits, including biochemical index and cognitive function scores (MMSE, WMS and WCST) between $\mathrm{AD}$ group and controls was carried out using Independent-Samples $t$-Test. The effects of three SNPs on serum lipid levels, the age-at-onset and cognitive function scores were investigated by one-way ANOVA. Univariate analysis of variance was applied to assess the interactive effect of these gene variants on lipid profiles. Chi-square $\left(x^{2}\right)$ test was used to compare genotype and allele frequency differences between $\mathrm{AD}$ cases and controls. Standard goodness-of-fit test was used to test the HardyWeinberg equilibrium. Multivariate logistic regression analysis was done in order to evaluate the simultaneous influence of these genetic variations and some environmental factors on the risk of AD. The estimated odds ratios (ORs) were adjusted for the effect of significant covariates, such as age, gender and education. All statistical tests were two-sided. A P value of less than 0.05 was considered statistically significant. All statistical tests were carried out using SPSS 13.0.

\section{Results}

\section{General characteristics and serum lipid levels}

There were no significant differences in age, gender and education structure, systolic blood pressure, fasting blood glucose, TG, LDL-C, apoA-I, apoB levels and the percentages of history of smoking, alcohol, diabetes,

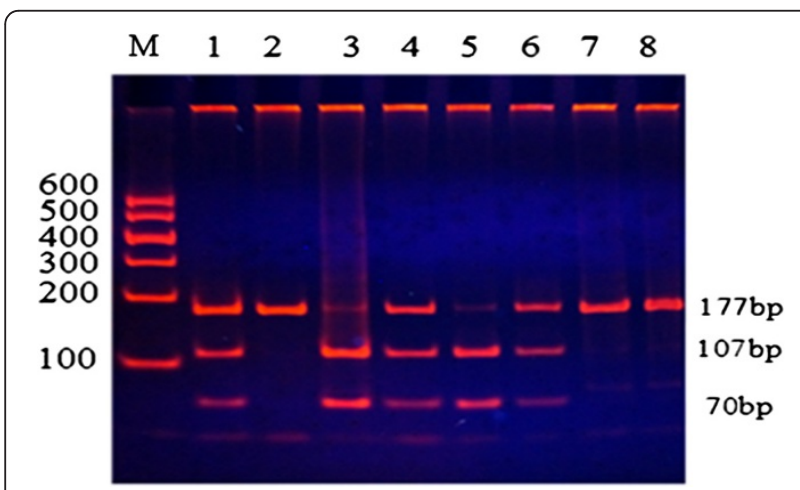

Figure 1 Genotyping of PCR products of ABCA1R219K. Lane M, 100 bp Marker Ladder; Lanes 1/4/6, RK genotype (177 bp, 107 bp and $70 \mathrm{bp}$ ); Lane 2/7/8, RR genotype (177 bp); and Lanes 3/5, KK genotype (107 bp and $70 \mathrm{bp}$ ).

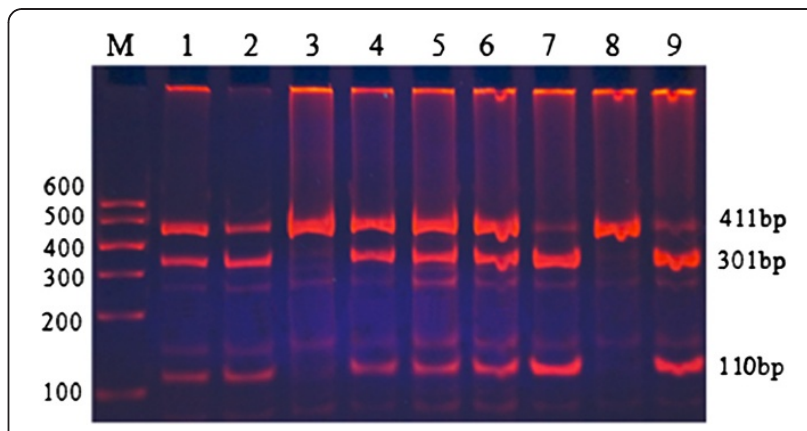

Figure 2 Genotyping of PCR products of LIPC-250 G/A. Lane M, 100 bp Marker Ladder; Lanes 1/2/4/5/6, GA genotype (411 bp, $301 \mathrm{bp}$ and $110 \mathrm{bp}$ ); Lane 3/8, GGgenotype (411 bp); and Lanes 7/9, AA genotype (301 bp and $110 \mathrm{bp}$ ).

hypertension and CAD between the two groups in the present study $(P>0.05)$. The levels of diastolic blood pressure and TC, the percentages of history of hyperlipidemia in $\mathrm{AD}$ group were higher than that in controls, whereas HDL-C level was lower than that of controls $(P<0.05)$ (Table 1$)$.

\section{Comparison of genotypes and alleles between cases and controls}

Three ABCA1R219K genotypes(RR, RK, KK), three LIPC-250 G/A genotypes (GG, GA, AA) and CETPTaq1B genotypes (B1B1, B1B2, B2B2) were detected and their genotype distributions in cases were consistent with Hardy-Weinberg equilibrium ( $\mathrm{R} 219 \mathrm{~K}, \mathrm{x}^{2}=1.674, \mathrm{df}=2$, $P=0.433 ; \quad$ LIPC-250 G/A, $X^{2}=4.163, \quad \mathrm{df}=2, P=0.125$; CETPTaq1B, $\left.X^{2}=2.047, \mathrm{df}=2, P=0.359\right)$, but in controls, with the exception of ABCA1R219K $\left(x^{2}=0.539, \mathrm{df}=2\right.$, $P=0.764)$, the polymorphisms of $-250 \mathrm{G} / \mathrm{A}$ and Taq1B both departed from HWE.

ABCA1R219K: There was significant difference in the frequencies of three genotypes between the $\mathrm{AD}$ patients and controls $\left(X^{2}=8.777, P=0.012\right)$. The frequency of KK

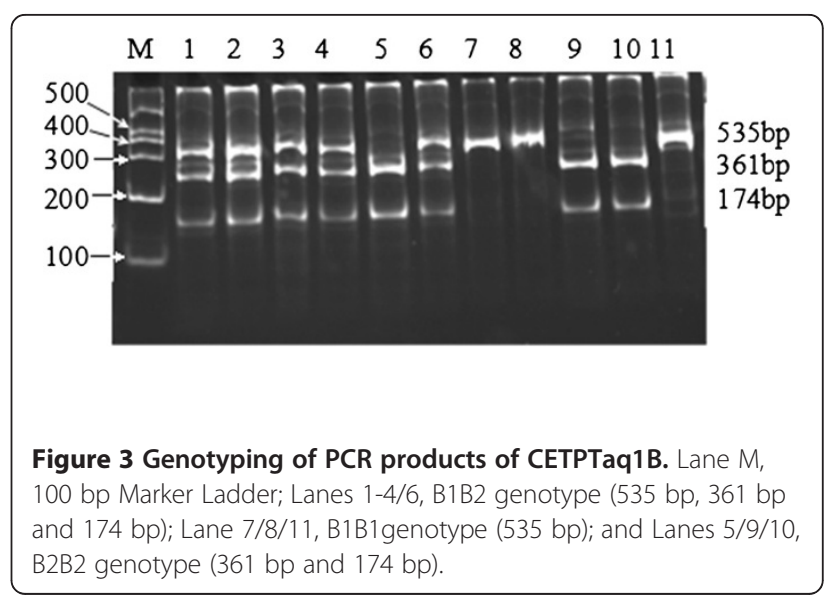


Table 1 Comparison of general characteristics and serum lipids between AD patients and controls

\begin{tabular}{|c|c|c|c|c|}
\hline Variable & Cases & Controls & $t$-value or $x^{2}$ & $P$ \\
\hline $\bar{N}$ & 104 & 104 & & \\
\hline Age(years) & $77.8 \pm 6.74$ & $76.5 \pm 6.14$ & -1.495 & 0.137 \\
\hline Male/female & $57 / 47$ & $56 / 48$ & 0.019 & 0.889 \\
\hline Systolic blood pressure $(\mathrm{mmHg})$ & $138.1 \pm 19.5$ & $134.7 \pm 19.5$ & -1.239 & 0.217 \\
\hline Diastolic blood pressure $(\mathrm{mmHg})$ & $79.6 \pm 9.56$ & $76.6 \pm 9.65$ & -2.256 & 0.025 \\
\hline Cigarette smoking[n(\%)] & $27(26.0)$ & $40(38.8)$ & 3.918 & 0.048 \\
\hline Alcohol consumption[n(\%)] & $8(7.7)$ & $6(5.8)$ & 0.286 & 0.593 \\
\hline History of hypertension[n(\%)] & $58(56.3)$ & $64(64.6)$ & 1.466 & 0.226 \\
\hline History of hyperlipidemia[n(\%)] & $44(42.3)$ & $27(26.0)$ & 6.180 & 0.013 \\
\hline History of diabetes[n(\%)] & $26(25.0)$ & 15(15.2) & 3.052 & 0.081 \\
\hline History of $\mathrm{CHD}[\mathrm{n}(\%)]$ & $46(44.7)$ & $41(41.4)$ & 0.217 & 0.641 \\
\hline Education(proportion of high school and above level) & $17(16.3)$ & 36(34.6) & 9.140 & 0.003 \\
\hline $\mathrm{TG}(\mathrm{mmol} / \mathrm{L})$ & $1.36 \pm 0.62$ & $1.32 \pm 0.71$ & -0.909 & 0.364 \\
\hline $\mathrm{TC}(\mathrm{mmol} / \mathrm{L})$ & $4.48 \pm 0.89$ & $4.10 \pm 1.04$ & -2.826 & 0.005 \\
\hline $\mathrm{HDL}-\mathrm{C}(\mathrm{mmol} / \mathrm{L})$ & $1.33 \pm 0.31$ & $1.44 \pm 0.31$ & 2.450 & 0.015 \\
\hline $\mathrm{LDL}-\mathrm{C}(\mathrm{mmol} / \mathrm{L})$ & $2.46 \pm 0.66$ & $2.40 \pm 0.82$ & -0.848 & 0.397 \\
\hline ApoA-I(g/L) & $1.17 \pm 0.28$ & $1.21 \pm 0.22$ & 1.162 & 0.247 \\
\hline $\mathrm{ApoB}(\mathrm{g} / \mathrm{L})$ & $0.79 \pm 0.22$ & $0.80 \pm 0.22$ & 0.089 & 0.929 \\
\hline
\end{tabular}

TC, Total cholesterol; TG, Triglycerides; HDL-C, highdensity lipoprotein cholesterol; LDL-C, low-density lipoprotein cholesterol; Apo, Apolipoproteins.

genotype in $\mathrm{AD}$ group was obviously lower than that in controls $\left(X^{2}=5.261, P=0.022\right)$. The frequency of $K$ allele (KK + RK genotype) in AD patients was $54.8 \%$, significantly lower than that of controls $(70.2 \%, P=0.022)$. No significant difference in $\mathrm{R}$ or $\mathrm{K}$ allele frequency was found between the two groups $(P>0.05)$.

LIPC-250 G/A: Significant differences in the frequencies of three genotypes (GG,GA and AA) between the $\mathrm{AD}$ patients and controls were determined $\left(\chi^{2}=7.925\right.$, $P=0.019)$. The frequency of GG genotype in AD group was obviously higher than that of controls $(27.9 \%$ $\left.\& 13.5 \%, X^{2}=5.233, P=0.022\right)$. The frequency of GA + AA genotype in $\mathrm{AD}$ patients was significantly lower than that of controls $(72.1 \% \& 86.5 \%, P=0.016)$. There was no significant difference in the frequency comparison of $G$ allele and A allele.

CETPTaq1B: The genotype distributions of the Taq1B polymorphism in AD cases differed from that of controls $\left(\chi^{2}=8.102, P=0.017\right)$. AD cases showed significantly higher B1B1 genotype frequency compared to controls (27.9\% versus $14.4 \% ; P=0.035$ ). No significant difference between both groups was determined in allele frequencies $(P>0.05)$. Distribution of all genotypes and alleles were showed in Table 2.

\section{SNPs and serum lipid levels}

For the first time we performed genetic analysis of several common polymorphisms of ABCA1, LIPC and CETP in AD patients and control subjects for the association with serum lipid levels, and elucidated that the important genetic factors could influence cholesterol levels in our population. For ABCA1 R219K polymorphism, there were significantly higher levels of HDL-C and apoA-I in the carriers of KK genotype and $\mathrm{K}$ allele $(P<0.05)$. During RR,RK,KK genotypes, the levels of HDL-C and apoA-I significantly increased in ascending order $(P<0.05)$, with TG level decreased but no statistically significance found $(P>0.05)$. We didn't found any positive association between R219K SNP and plasma levels of TC,LDL-C and apoB. In all serum lipids, only apoA-I had been found distinct relevance with LIPC$250 \mathrm{G} / \mathrm{A}$. The level of apoA-I was highest in AA genotype, followed by GA and GG genotypes in total subjects. The subjects carrying A allele had higher plasma apoA-I level than non-carriers in both whole population and the control group. Nevertheless, no significant association was reached in our study for serum HDL-C level with SNP of -250 G/A. In addition, B2B2 genotype of CETP Taq1B showed significant association with higher plasma HDL-C levels than other genotypes $(F=5.598, P=0.004)$. After stratifying by gender, this change was only found in females $(F=3.404, \mathrm{df}=2$, $P=0.038)$. And there was obviously lower HDL-C levels in B1 allele carriers $(1.24 \pm 0.35 \mathrm{mmol} / \mathrm{L})$ than in noncarriers $(1.45 \pm 0.35 \mathrm{mmol} / \mathrm{L}, t=-2.463, P=0.015)$ (Table 3$)$.

We have further assessed the impact of the combined effects of these frequent single-nucleotide polymorphisms (SNPs) in the HDL catabolic pathway on the lipid levels. 
Table 2 Genotype distribution and allele frequencies of these three polymorphisms (ABCA1R219K, LIPC-250 G/A and CETP Taq1B) in cases and controls

\begin{tabular}{|c|c|c|c|c|}
\hline Genotypes and alleles & AD patients $(n / \%)$ & Controls (n/\%) & $x^{2}$ & $P$ \\
\hline \multicolumn{5}{|l|}{ ABCA1R219K } \\
\hline $\mathrm{RR}$ & $47(45.2)$ & $31(29.8)$ & 3.282 & 0.070 \\
\hline RK & $51(49.0)$ & $56(53.8)$ & 0.234 & 0.629 \\
\hline KK & $6(5.8)$ & $17(16.3)$ & 5.261 & 0.022 \\
\hline \multicolumn{5}{|c|}{$X^{2}=8.777 P=0.012$} \\
\hline$R / K(\%)$ & $70 / 30$ & $57 / 43$ & 3.646 & 0.056 \\
\hline \multicolumn{5}{|l|}{ LIPC-250 G/A } \\
\hline GG & 29(27.9) & $14(13.5)$ & 5.233 & 0.022 \\
\hline GA & $64(61.5)$ & $82(78.8)$ & 2.219 & 0.136 \\
\hline $\mathrm{AA}$ & 11(10.6) & $8(7.7)$ & 0.474 & 0.491 \\
\hline \multicolumn{5}{|c|}{$X^{2}=7.925 P=0.019$} \\
\hline $\mathrm{G} / \mathrm{A}(\%)$ & $59 / 41$ & $53 / 47$ & 0.731 & 0.393 \\
\hline \multicolumn{5}{|l|}{ CETP Taq1B } \\
\hline $\mathrm{B} 1 \mathrm{~B} 1$ & $14(13.5)$ & $9(8.7)$ & 1.087 & 0.297 \\
\hline B1B2 & $61(58.7)$ & $80(76.9)$ & 2.560 & 0.110 \\
\hline B2B2 & 29(27.9) & $15(14.4)$ & 4.455 & 0.035 \\
\hline \multicolumn{5}{|c|}{$X^{2}=8.102 P=0.017$} \\
\hline B1/B2(\%) & $57 / 43$ & $53 / 47$ & 0.323 & 0.570 \\
\hline
\end{tabular}

There existed evident combined genotype effect of the ABCA1 R219K and the LIPC-250 G/A polymorphisms on HDL-C levels in total subjects: the carriers of the KK/AA genotype showed the highest levels of HDL-C (2.07 +/$0.11 \mathrm{mmol} / \mathrm{L}$ ), whereas those carrying the RR/GG genotype showed the lowest $(1.07+/-0.22 \mathrm{mmol} / \mathrm{L})$ (Table 4). There was no significant difference of HDL-C level among subjects carrying CETP Taq1B genotypes with others.

SNPs and age-on-set and cognitive test scores

We examined the association of these polymorphisms with age-on-set of $\mathrm{AD}$ cases, but found no significant

Table 3 SNPs and serum lipid levels and age-on-set

\begin{tabular}{|c|c|c|c|c|c|c|c|c|c|c|c|c|c|}
\hline \multicolumn{2}{|c|}{ Parameter } & \multicolumn{4}{|c|}{ ABCA1R219K } & \multicolumn{4}{|c|}{ LIPC-250 G/A } & \multicolumn{4}{|c|}{ CETP Taq1B } \\
\hline & & RR & RK & KK & $\mathrm{RK}+\mathrm{KK}$ & GG & GA & $\mathrm{AA}$ & $\mathrm{GA}+\mathrm{AA}$ & B1B1 & B1B2 & B2B2 & $\mathrm{B} 1 \mathrm{~B} 2+\mathrm{B} 1 \mathrm{~B} 1$ \\
\hline \multirow[t]{6}{*}{$\begin{array}{l}\text { Serum lipid } \\
\text { levels }\end{array}$} & $\begin{array}{c}\mathrm{TG} \\
(\mathrm{mmol} / \mathrm{L})\end{array}$ & $\begin{array}{c}1.39 \pm \\
0.80\end{array}$ & $\begin{array}{c}1.33 \pm \\
0.57\end{array}$ & $\begin{array}{c}1.20 \pm \\
0.60\end{array}$ & $\begin{array}{c}1.31 \pm \\
0.58\end{array}$ & $\begin{array}{c}1.24 \pm \\
0.63\end{array}$ & $\begin{array}{c}1.35 \pm \\
0.69\end{array}$ & $\begin{array}{c}1.50 \pm \\
0.55\end{array}$ & $\begin{array}{c}1.37 \pm \\
0.68\end{array}$ & $\begin{array}{c}1.25 \pm \\
0.53\end{array}$ & $\begin{array}{c}1.38 \pm \\
0.70\end{array}$ & $\begin{array}{c}1.32 \pm \\
0.71\end{array}$ & $1.34 \pm 0.67$ \\
\hline & $\begin{array}{c}\mathrm{TC} \\
(\mathrm{mmol} / \mathrm{L})\end{array}$ & $\begin{array}{c}4.22 \pm \\
0.97\end{array}$ & $\begin{array}{c}4.34 \pm \\
0.99\end{array}$ & $\begin{array}{c}4.31 \pm \\
0.96\end{array}$ & $\begin{array}{c}4.34 \pm \\
0.99\end{array}$ & $\begin{array}{c}4.12 \pm \\
0.89\end{array}$ & $\begin{array}{c}4.32 \pm \\
0.99\end{array}$ & $\begin{array}{c}4.45 \pm \\
1.03\end{array}$ & $\begin{array}{c}4.34 \pm \\
1.00\end{array}$ & $\begin{array}{c}4.21 \pm \\
0.98\end{array}$ & $\begin{array}{c}4.30 \pm \\
0.95\end{array}$ & $\begin{array}{c}4.39 \pm \\
1.18\end{array}$ & $4.28 \pm 0.96$ \\
\hline & $\begin{array}{c}\mathrm{HDL}-\mathrm{C} \\
(\mathrm{mmol} / \mathrm{L})\end{array}$ & $\begin{array}{c}1.27 \pm \\
0.28\end{array}$ & $\begin{array}{c}1.39 \pm \\
0.24^{a}\end{array}$ & $\begin{array}{c}1.76 \pm \\
0.41\end{array}$ & $\begin{array}{l}1.45 \pm \\
0.31^{a^{*}}\end{array}$ & $\begin{array}{c}1.35 \pm \\
0.33\end{array}$ & $\begin{array}{c}1.39 \pm \\
0.30\end{array}$ & $\begin{array}{c}1.41 \pm \\
0.37\end{array}$ & $\begin{array}{c}1.40 \pm \\
0.31\end{array}$ & $\begin{array}{l}1.37 \pm \\
0.43^{c}\end{array}$ & $\begin{array}{c}1.21 \pm \\
0.32\end{array}$ & $\begin{array}{l}1.46 \pm \\
0.35^{c^{*}}\end{array}$ & $1.24 \pm 0.35^{d}$ \\
\hline & $\begin{array}{c}\mathrm{LDL}-\mathrm{C} \\
(\mathrm{mmol} / \mathrm{L})\end{array}$ & $\begin{array}{c}2.35 \pm \\
0.72\end{array}$ & $\begin{array}{c}2.49 \pm \\
0.76\end{array}$ & $\begin{array}{c}2.44 \pm \\
0.75\end{array}$ & $\begin{array}{c}2.48 \pm \\
0.75\end{array}$ & $\begin{array}{c}2.29 \pm \\
0.73\end{array}$ & $\begin{array}{c}2.45 \pm \\
0.74\end{array}$ & $\begin{array}{c}2.58 \pm \\
0.75\end{array}$ & $\begin{array}{c}2.47 \pm \\
0.74\end{array}$ & $\begin{array}{c}2.38 \pm \\
0.73\end{array}$ & $\begin{array}{c}2.45 \pm \\
0.73\end{array}$ & $\begin{array}{c}2.44 \pm \\
0.86\end{array}$ & $2.43 \pm 0.73$ \\
\hline & $\begin{array}{c}\text { apoA-1 } \\
(\mathrm{g} / \mathrm{L})\end{array}$ & $\begin{array}{c}1.11 \pm \\
0.25\end{array}$ & $\begin{array}{l}1.20 \pm \\
0.23^{\mathrm{a}}\end{array}$ & $\begin{array}{c}1.39 \pm \\
0.25\end{array}$ & $\begin{array}{l}1.24 \pm \\
0.25^{\mathrm{a}^{*}}\end{array}$ & $\begin{array}{c}1.11 \pm \\
0.25\end{array}$ & $\begin{array}{l}1.20 \pm \\
0.24^{b}\end{array}$ & $\begin{array}{l}1.29 \pm \\
0.34^{b^{*}}\end{array}$ & $\begin{array}{l}1.21 \pm \\
0.25^{b}\end{array}$ & $\begin{array}{c}1.22 \pm \\
0.29\end{array}$ & $\begin{array}{c}1.17 \pm \\
0.24\end{array}$ & $\begin{array}{c}1.25 \pm \\
0.28\end{array}$ & $1.18 \pm 0.25$ \\
\hline & $\begin{array}{l}\text { apoB } \\
(\mathrm{g} / \mathrm{L})\end{array}$ & $\begin{array}{c}0.79 \pm \\
0.23\end{array}$ & $\begin{array}{c}0.80 \pm \\
0.22\end{array}$ & $\begin{array}{c}0.78 \pm \\
0.23\end{array}$ & $\begin{array}{c}0.80 \pm \\
0.22\end{array}$ & $\begin{array}{c}0.77 \pm \\
0.25\end{array}$ & $\begin{array}{c}0.80 \pm \\
0.22\end{array}$ & $\begin{array}{c}0.83 \pm \\
0.22\end{array}$ & $\begin{array}{c}0.80 \pm \\
0.22\end{array}$ & $\begin{array}{c}0.78 \pm \\
0.20\end{array}$ & $\begin{array}{c}0.79 \pm \\
0.23\end{array}$ & $\begin{array}{c}0.84 \pm \\
0.26\end{array}$ & $0.79 \pm 0.22$ \\
\hline $\begin{array}{l}\text { Age-on-set } \\
\text { (years) }\end{array}$ & & $\begin{array}{c}73.2 \pm \\
7.89\end{array}$ & $\begin{array}{c}72.6 \pm \\
6.92\end{array}$ & $\begin{array}{c}73.2 \pm \\
6.43\end{array}$ & $\begin{array}{c}72.6 \pm \\
6.82\end{array}$ & $\begin{array}{c}73.2 \pm \\
8.36\end{array}$ & $\begin{array}{c}73.1 \pm \\
6.87\end{array}$ & $\begin{array}{c}70.9 \pm \\
7.34\end{array}$ & $\begin{array}{c}72.8 \pm \\
6.94\end{array}$ & $\begin{array}{c}73.0 \pm \\
7.04\end{array}$ & $\begin{array}{c}72.8 \pm \\
7.76\end{array}$ & $\begin{array}{c}72.9 \pm \\
6.04\end{array}$ & $72.9 \pm 7.49$ \\
\hline
\end{tabular}

${ }^{\mathrm{a}} P<0.05$ in comparison with RR genotype, ${ }^{\mathrm{a}}{ }^{*} P<0.01$ in comparison with RR genotype.

${ }^{\mathrm{b}} P<0.05$ in comparison with GG genotype, ${ }^{\mathrm{b}^{*}} P<0.01$ in comparison with GG genotype.

${ }^{c} P<0.05$ in comparison with B1B2 genotype, ${ }^{C^{*}} P<0.01$ in comparison with B1B2 genotype.

${ }^{\mathrm{d}} P<0.05$ in comparison with B2B2 genotype. 
Table 4 Combination of ABCA1 R219K and LIPC -250 G/A variants and serum HDL-C levels(mmol/L)

\begin{tabular}{llccc}
\hline & & \multicolumn{3}{c}{ LIPC-250 G/A genotypes } \\
\cline { 3 - 5 } & & GG & GA & AA \\
\hline ABCA1 R219 K genotypes & RR & $1.07 \pm 0.22$ & $1.33 \pm 0.82$ & $1.19 \pm 0.26$ \\
& RK & $1.40 \pm 0.26$ & $1.36 \pm 0.24$ & $1.52 \pm 0.19$ \\
& KK & $2.02 \pm 0.66$ & $1.70 \pm 0.40$ & $2.07 \pm 0.11$ \\
& \multicolumn{4}{c}{$F=3.930 P=0.004$} \\
\hline
\end{tabular}

result. We also determined the association of these genetic variations with quantitative measures of cognition such as MMSE, WMS and WCST scores. In whole population, subjects carrying ABCA1 $219 \mathrm{~K}$ allele or LIPC -250A allele obtained higher MMSE or WMS scores than non-carriers, however, no significant association was observed in AD group or controls. We didn't find any effect of CETPTaq1B polymorphism on cognitive test scores.

\section{Logistic regression analysis:risk factors for $A D$;} simultaneous effects of ABCA1,LIPC and CETP

Unconditional logistic regression analysis was done for the assessment of the influence of age, gender, education, TC, HDL-C and ABCA1, LIPC, CETP minor alleles, and the interaction terms (ABCA1 $\times$ LIPC $\times$ CETP) on the risk for developing AD. The analyses revealed no significant influences of CETPTaq1B polymorphism, TC and HDL-C on the risk of AD. It was evident that, while there was no obvious interaction, both minor alleles (ABCA1 and LIPC) had statistically significant independent effects on $\mathrm{AD}$ risk $(P=0.005, \mathrm{OR}=0.405,95 \%$ CI:0.217-0.758 and $P=0.018, \quad O R=0.405,95 \% C I: 0.191-$ 0.858 , respectively). Moreover, it was also suggested that age $(P=0.003, \quad$ OR $=2.620,95 \% \mathrm{CI}: 1.381-4.972)$ and levels of education $(\mathrm{B}=-1.052$, adjustedOR $=0.349, \mathrm{P}=0.004,95 \%$ CI:0.172-0.710) had an independent significant association with $\mathrm{AD}$ respectively. The final model is shown in Table 5.

\section{Discussion}

Alzheimer's disease is a multifactorial disease but its aetiology and pathophisiology still has not been fully understood. Similar to most complex diseases, AD is likely to be influenced not only by genetic factors, but also by environmental components. One environmental

Table 5 Logistic regression analysis:risk factors for AD

\begin{tabular}{lcccc}
\hline Variable & B & $\boldsymbol{P}$ & OR & 95\%Cl \\
\hline age & 0.963 & 0.003 & 2.620 & $1.381-4.972$ \\
education & -1.052 & 0.004 & 0.349 & $0.172-0.710$ \\
219K allele & -0.903 & 0.005 & 0.405 & $0.217-0.758$ \\
-250A allele & -0.905 & 0.018 & 0.405 & $0.191-0.858$ \\
\hline
\end{tabular}

factor which role in AD pathogenesis remains controversial based on systematic review of case-control and cohort studies is dyshomeostasis of cholesterol [9]. It is well known that dyslipidaemia is a complex trait caused by multiple environmental and genetic factors and their interactions. This study aimed to investigate variations of several cholesterol-related genes and correlation to serum lipid levels and risk of LOAD in Chinese Southern Han population in Hunan Province.

The relationship between cholesterol levels in plasma and risk of AD has been still a matter of discussion. In our study, the level of $\mathrm{TC}$ in $\mathrm{AD}$ patients was higher than that in controls $(P<0.01)$, whereas HDL-C level lower than that in controls $(P<0.05)$, in line with previous studies indicating lower plasma HDL-C levels, higher LDL-C levels, or increased TC level in AD cases when compared to controls $[11,68,69]$. But after adjusting other factors in logistic regression analysis we didn't find any potential association of serum TC or HDL-C with risk of AD. Hall $\mathrm{K}$ et al. [12] and Helzner EP [4] et al. respectively had reported an obvious association of plasma TC or LDL-C levels with increased risk of LOAD and the rate of cognitive decline in the eldly, but the former result only for carriers without APOE\&4 [12]; Recently higher HDL-C level (>55 mg/dL) was demonstrated with lower risk for $\mathrm{AD}$ in a large prospective cohort study carried out in 1130 cognitively intact old people by Reitz C et al. [10]. However, this was contradicted by some studies demonstrating increased cholesterol level was linked to reduced $\mathrm{AD}$ risk [70,71]. Furthermore, high midlife TC, not late-life TC, was associated with increased risk of $\mathrm{AD}$ and cognitive decline, that was supported by a systematic review of prospective studies with meta-analysis [14]. It remained controversial due to ethnic or region specificity, carrying apoEs4 allele or not, difference of life styles such as fat intake and BMI [72,73], physical activity and oxidative stress, as well as homocysteine by likely impairing apoE3 function for HDL [74]. It was reported that using some drugs might produce any uncertain effects, for example, taking statins could slow the rate of cognitive decline and delay the onset of $\mathrm{AD}$ and reduce risk of dementia in the eldly [17,75], and donepezil hydrochloride using for $\mathrm{AD}$ patients may cause up-alteration of serum TG,TC and LDL-C [76]. These factors may be of equal importance when considering $\mathrm{AD}$ risk. Although numerous hypotheses have been advanced to explain the role of cholesterol in the pathogenesis, it remained to be elucidated. Currently, it has been extensively recognized that cholesterol may be associated closely with brain $A \beta$ levels. Animal studies showed that hypercholesterolemia may lead to increase brain $A \beta$ levels [20]. Recent convincing evidence by Lesser et al. performed in $281 \mathrm{AD}$ patients indicated that serum TC and LDL levels were clearly positively correlated with densities of neuritic plaques in both neocortex and hippocampal 
regions [77]. Further research to determine if dyslipemia results in a decreased risk of LOAD would strengthen these findings.

In this pilot study we determined an apparent association between the polymorphism of ABCA1 R $219 \mathrm{~K}$ and $\mathrm{AD}$. The frequencies of carrying both KK genotype and $\mathrm{K}$ allele in $\mathrm{AD}$ group were obviously lower than that of controls $\left(x^{2}=5.261, P=0.022\right)$, and logistic regression analysis showed that $\mathrm{K}$ allele may be an independent protective factor for $\mathrm{AD}(P=0.005, \mathrm{OR}=0.405,95 \%$ CI:0.217-0.758), consistent with previous report by Wang $\mathrm{F}$ et al. that risk of $\mathrm{AD}$ was significantly decreased in $\mathrm{K}$ allele or $\mathrm{KK}$ homozygote carriers compared with RR genotypes carriers [57]. Nevertheless, some studies in other populations have excluded the association of ABCA1 gene with LOAD $[38,78]$, while others have shown an increased risk of AD for female $219 \mathrm{~K}$ allele carriers [56]. Important differences in the population sizes, genetic composition, and background environment of the populations studied such as diets may be partly responsible for mutative AD susceptibility and these discordant results. The minor allele frequency of R219K was reported $25 \%$ in Caucasian populations [79], 46\% in Europeans [65]. In addition, we didn't find any correlation with age-on-set of $\mathrm{AD}$, however, Wollmer MA et al. once reported that $\mathrm{A}$ allele was associated with delayed age-at-onset by 1.7 years on average [38].

Mechanisms via which this polymorphism could affect pathogenesis of $\mathrm{AD}$ remain to be elucidated. Some studies focused on pathological mechanism have suggested that ABCA1 mRNA expression was significantly elevated at the earliest stage of dementia, and positively correlated with neuropathological stages and neuritic plaque density counts and dementia severity, through comparison of postmortem hippocampus from persons at different stages of $\mathrm{AD}$ and cognitively intact normal donors by Akram A et al. [31]. And transgenic animal models have repeatedly shown the influence of loss of $\mathrm{ABCA1}$ on apoE lipidation, $\mathrm{A} \beta$ production or deposition and cognitive impairment [80]. Secondly, ABCA1 gene is located on 9q31.1, just closing to susceptible loci region of LOAD oncome [81]. Furthermore, $\mathrm{K}$ allele may produce a benefit profile of serum lipids [82]. Therefore, it is also understandable that carrying $\mathrm{K}$ allele may be correlated with protecting from AD. However, much larger sample would be needed to confirm such an interaction.

ABCA1 is a member of a superfamily of membrane proteins as a key enzyme in regulating plasma HDL-C and apoA-I metabolism [83]. Many conflicting results from previous studies have evaluated the associations of $\mathrm{R} 219 \mathrm{~K}$ polymorphism with level of HDL-C and risk of developing CAD $[82,84,85]$. However, little work about the association of this genetic variation with plasma lipids in $\mathrm{AD}$ patients has been assessed. In this pilot study, we first reported the association of $\mathrm{R} 219 \mathrm{~K}$ gene variants with lipids in $\mathrm{AD}$ patients, suggesting the possible involvement of cholesterol with $\mathrm{AD}$. There was significantly higher levels of HDL-C and apoA-I in the carriers of KK genotype and $\mathrm{K}$ allele $(P<0.05)$ in either $\mathrm{AD}$ patients or controls, similar to several previous findings $[82,86,87]$. Recent meta-analysis using thousands of samples established that this association only presented in Asian, not in White populations $[82,86]$. Genvigir FD et al. determined that $\mathrm{K}$ allele was correlated with higher apoA-I level in Brazilian individuals [88]. However, other studies failed to find any significant influence of R219K variation on HDL-C or other lipid parameters levels [85,89-91]. The explanation for these contradictory findings has been set on not only the limited effects of gene variation but gene-environment interactions. Different populations have discrepant HDL-C levels, such as relatively lower in Turks [92]. KK genotype of ABCA1R219K polymorphisms has been reported linked to a 5.5\% higher concentration of small HDL particles [93]. Moreover, controversial conclusion may vary with other factors such as age [94], gender [95], smoking [96], obesity [97] and existing linkage disequilibrium or interactive effect with other candidate genes [98]. In addition, the influence of $A B C A 1$ gene variants on other lipid molecules and enzymes secondarily can mildly influence HDL concentration. Clee $\mathrm{SM}$, Pasdar A and Li J et al. reported downward trend of TG level during RR,RK,KK genotypes and $219 \mathrm{~K}$ allele carriers $[65,99,100]$. This trend was replicated in our population, but no statistically significance found. Further investigations are needed to prove the influence of $\mathrm{ABCA1}$ polymorphisms on serum lipid levels and to determine whether it could be a genetic determinant of AD.

Previous studies have shown that the A allele of the LIPC-250 G/A and the B1 allele of Taq1B in the intron region of CETP were associated with decrease in HL activity and CETP activity and elevation of HDL-C levels [49,101]. The present study first revealed the association of $-250 \mathrm{G} /$ A variants with plasma lipids in AD patients in the Chinese population, only finding an significant effect on serum apoA-I levels, which was higher in the subjects carrying A allele or AA genotype than other genotypes or alleles carriers in total subjects and the control group. It was similar to the previous research studied in type 2 diabetes and CAD patients by Wei M et al. [52]. Nevertheless, we found no significant effect on HDL-C and other lipoprotein levels. To date, there has been considerable evidence about $-250 \mathrm{G} / \mathrm{A}$ variant and plasma lipoprotein concentrations, but the result remains inconsistent [52,102-104]. Influence of gender-specificity on the association was found in some studies [51,103,104]. Transgenic mice studies has demonstrated that overexpression of HL has led to a marked reduction in plasma HDL-C [105], however, there have existed many contradictory results in clinical epidemiological studies, which may be attributed to various factors, such as (i)restriction in terms of sample size and ethnic 
diversity; (ii)the integrated effects of multiple polymorphisms of genes, for instance, Wood $\mathrm{KC}$ et al. indicated interactions during LIPC-514C/T and LIPC-250 G/A and apoE gene polymorphisms could distinctly influence serum lipid profiles [106]; (iii)both having pro-atherogenic and antiatherogenetic properties for $\mathrm{HL}[107,108]$; (iv)related to HDL subclasses, mainly as $\mathrm{HDL}_{2}-\mathrm{C}$ [49], etc. The proportion of variation in HDL-C attributable to polymorphisms within the HL gene is probably no more than $25 \%[40,109]$. However, it is not clear whether the promoter polymorphisms was functional or merely a marker of another physiological polymorphism located elsewhere, because of complete linkage disequilibrium [47].

CETP has its capacity to mediate transferring of neutral lipids among the lipoproteins by reversely exchanging triglycerides and cholesteryl ester between TG-rich lipoproteins and HDL, producing HDL with reduced cholesteryl ester and increased TG [110]. Most previous studies examining the relationship between CETP variants and plasma HDL-C levels and CAD risk have focused on the intronic Taq1B variant [101]. Our research first indicated that B2B2 genotype was significantly associated with higher plasma HDL-C levels than other genotypes, and HDL-C levels in B1 allele carriers $(1.24 \pm 0.35 \mathrm{mmol} / \mathrm{L})$ was obviously lower than that in non-carriers $(1.45 \pm 0.35 \mathrm{mmol} / \mathrm{L}$, $P=0.015)$ in AD patients, supporting previous and recent studies in which homozygous minor allele genotypes or B2 allele would be associated with highest HDL-C concentrations [43,44,98,111]. However, there also have been addressed no distinct anti-atherogenic potential of this polymorphism in some studies [102,112]. It may be due to diverse genotype or allele frequencies in different racial and regional groups. The meta-analyse in 2008 suggested the minor allele (B2 allele) frequency in the Whites was the same as East Asian populations (0.42) [101], in accordance with 0.43 and 0.47 respectively in our AD participants and controls. We also found the effect of B2 allele or homozygous genotype on HDL-C more apparent in females, which was probably associated with modification of hormone in menopausal status [113]. Such genetic testing is limited by the fact that each sequence variant explains only a modest fraction of the variance (2\% or less) in lipid levels [114]. However, the combination of several lipid-related polymorphisms perhaps could improve risk prediction.

CETP-mediated triglyceride enrichment of HDL-C notably increases the ability of hepatic lipase to assemble HDL-C [41]. So the potential interaction between LIPC and CETP variants on lipid levels needed to be elucidated. But our study indicated that there was no significant effect of combinations of CETPTaqIB and LIPC -250 G/A or ABCA1 R219Kvariants on plasma HDL-C levels and other lipids. We found a significant interaction of ABCA1 R219K and LIPC-250 G/A polymorphisms on HDL-C levels in the total subjects $(F=3.930, P=0.004)$. Previous studies have shown that combinations of minor variants in these common polymorphisms could produce more pronounced effect on serum lipids $[43,98,115]$. However, recently a large cardiovascular cohort by Kathiresan et al. suggested that combinations of common SNPs only showed a weak association with alteration in HDL-C level [116]. The determinants of HDL-C levels are involved in not only gene variants, but also many environmental profiles. Approximately $50 \%$ of the inter-individual variation in serum HDL-C levels was considered to be genetically determined [117]. In addition, age, diet, smoking, alcohol, body mass index (BMI), physical activity [118] and different levels and distribution of HDL subclasses all play a role in determining individual HDL-C levels. CETP and $\mathrm{HL}$ are implicated in the metabolism of plasma lipoproteins, but the effects of CETP and LIPC genotypes on atherosclerosis may be dependent on LDL-receptor activity [119]. The relationship between HDL and these gene variants needs to be validated in a larger longitudinal study.

In the past decade, while a number of case-control studies have been carried out to investigate the relationships between LIPC or CETP polymorphisms and risk of atherosclerosis diseases $[43,51,52,101,115]$, little is known about their effect on neurodegenerative disease. In 2008 Haiyan Zhu et al. has detected three LIPC SNPs (rs6083,rs6084 and rs6074 in coding region) in three LOAD series, and recently in a German case-control sample (438 AD patients and 290 controls) Laws SM et al. also evaluated 25 single nucleotide polymorphisms (-250 G/A not included), however, no association with $A D$ was found $[60,61]$. Our study first showed that $-250 \mathrm{G} / \mathrm{A}$ variant may decrease the risk of AD after adjusting other factors like gender, age and education for logistic regression analysis. The independent protective effect of A allele may be understandable due to its implication in lipid metabolism involved in decreasing plasma HL activity, elevating HDL-C and apoA-I levels. There was significant difference in the A allele frequency in different regions and populations: 0.21 in American Caucasian, 0.47 and 0.45 in Japanese Americans and African Americans respectively [42,49], 0.63 in Korean [42] and 0.32 in Southern Brazilian population [51]. Moreover, the influences of APOE\&4 and other genes cholesterolrelated need to be taked into account.

Earlier research showed that in AD tissue CETP was extensively expressed in the astrocytes of gray matter as well as the white matter [120], so alteration of CETP activity might play a role for AD pathology. Several studies have showed CETP gene variants such as I405V,D442G may have a potential association with memory decline and dementia risk $[59,121,122]$. But others didn't find any positive results [123,124]. For TaqIB polymorphism, subsequent studies reported no statistically significant differences with 
respect to either genotype or allele frequencies between CETP TaqIB and AD [125]. And the same results maintained in the study of Xuanwu Hospital of our country by Chen DW et al. regardless of APOE $\varepsilon 4$ carrier status [59]. We also didn't find any correlation between TaqIB variation and $\mathrm{AD}$ risk in Hunan Han population, though AD cases showed significantly higher B1B1 genotype frequency compared to controls $(27.9 \%$ versus $14.4 \% ; P=0.035)$. Further studies combined with multi-ethnic research are warranted to determine the value of CETP variants for AD.

We further investigated interactive effect among these ABCA1 and LIPC and CETP variants on the risk of AD. These variants, which could decrease protein activity and increase HDL-C levels, should, in theory, decrease atherosclerosis and reduce the incidence of AD. However, in our case-control study, on adjusting for age, sex and education, logistic regression analysis revealed no statistically significant interaction.

In this pilot study, we first determined the association of these genetic variations with quantitative measures of cognition such as MMSE, WMS and WCST scores. The former two ones were used to examine the degree of memory impairment, and WCST implicated in evaluation of frontal behavioral function. ABCA1219K allele and LIPC-250A allele carriers were associated with higher MMSE or WMS scores in total sample, however, no significant difference was observed in AD patients or controls. This was in line with indication in logistic regression. This protective effect may be attributed to the beneficial effect of the ABCA1219K and LIPC-250A alleles on HDL-C. Pathological mechanism studies suggested ABCA1mRNA expression was positively correlated with Braak neuropathological stages and dementia severity [31]. And Hirsch-Reinshagen et al. has found that increased ABCA1 expression may result in improved cognition in amyloid mouse models [80]. However, there was no significant association of ABCA1 gene variants with MMSE scores in the literature [56]. Replication with a larger sample size and in other ethnic groups and standardization of test process is warranted.

Many environmental vascular risk factors such as age, smoking, obesity, abnormal lipid metabolism, physical inactivity and diabetes are thought to be necessary cocontributors or initiators of the disease process. We didn't find smoking, alcohol and diabetes had any distinct effect on AD incidence as well as sex. However, some studies have suggested female gender was associated with an increased risk of $\mathrm{AD}[78,126]$. Age did not significantly influence the risk of $A D$ in the study consisted of 241 German AD patients and 294 nondemented controls by Kölsch $\mathrm{H}$ et al. [78].

Currently, while the effect of education on the incidence of dementia and $\mathrm{AD}$ has not been stated universally, major studies reported to date as well as our finding have showed that higher education might shorten cognitive impairment and decrease $\mathrm{AD}$ risk. We found higher education may be an independent protective determinant of $\mathrm{AD}$, in accordance with the results in previous studies and the recent Epidemiological Clinicopathological Studies in Europe (EClipSE) that longer years in education were associated with decreased dementia risk and low educational attainment was associated with a higher risk of AD [126-128]. Reuser $\mathrm{M}$ et al. also found that higher education may delay incidence of cognitive decline and protect against cognitive impairment between age 55 and 75 by assessment in three ethnic groups in the US Health and Retirement Study [129]. But adjusting for age the Framingham Study by Cobb JLet al showed low educational attainment was not a risk factor for $\mathrm{AD}$ compared with those who earned a high school diploma (relative risk:1.04, 95\% CI:0.62 to 1.74) [130]. Further investigations are needed to prove the influence of education on risk of $\mathrm{AD}$ in Chinese Han population.

\section{Conclusion}

In summary, for the first time we reported a significant association of the ABCA1 R219K and LIPC-250A polymorphisms with sporadic AD risk and cognitive and memorial scores in Southern Chinese Han population, but no pronounced effect in CETP TaqIB SNP. We also provided preliminary evidence for the first time that these three variations were associated with serum lipids in $\mathrm{AD}$ patients. Hence, the combined study of common genetic variants as well as environmental risk factors, may contribute to the etiological understanding of the remaining fraction unexplained in AD. Replication with a larger sample size, more detailed individual information and more rare loci variants as well as other ethnic groups is warranted.

\section{Competing interests}

The authors declare that they have no competing interests.

\section{Authors' contributions}

JW, PW and ZX contributed to the design of the study. JW and PW contributed to the collection of all samples. JW, PW and ZX contributed to the analysis and interpretation of data. WC, WC and $\mathrm{HZ}$ contributed to the financial support. JW was responsible for finishing the article including all figures and tables. All authors contributed to critical revision of the paper. All authors have read the manuscript and gave their final approval for this version of the manuscript to be published.

\section{Acknowledgments}

This work was supported by a grant from the Science and Technology Plan of Hunan Province, China (2009FJ3054).

\section{Author details}

${ }^{1}$ Department of Neurology, The Second XiangYa Hospital of Central South University, No.139 of People's Middle Road, Changsha, Hunan Province 410011, People's Republic of China. ${ }^{2}$ Medical Center of Women and Children Health Hospital, Changsha, Hunan Province 410011, People's Republic of China.

Received: 8 February 2012 Accepted: 6 November 2012

Published: 26 November 2012 


\section{Reference}

1. Corder EH, Saunders AM, Strittmatter WJ, et al: Gene dose of apolipoprotein E type 4 allele and the risk of Alzheimer's disease in late onset families. Science 1993, 261:921-923.

2. Hartmann T: Cholesterol, A beta and Alzheimer's disease. Trends NeurosCi 2001, 24(11 Suppl):S45-S48.

3. Martins IJ, Hone E, Foster JK, et al: Apolipoprotein E, cholesterol metabolism, diabetes, and the convergence of risk factors for Alzheimer's disease and cardiovascular disease. Molecular Psychiatry 2006, 11:721-736.

4. Helzner EP, Luchsinger JA, Scarmeas $\mathrm{N}$, et al: Contribution of vascular risk factors to the progression in Alzheimer disease. Arch Neurol 2009, 66(3):343-348,

5. García-Lara JM, Aguilar-Navarro S, Gutiérrez-Robledo LM, et al: The metabolic syndrome, diabetes, and Alzheimer's disease. Rev Invest Clin 2010, 62(4):343-349.

6. Honig LS, Kukull W, Mayeux R: Atherosclerosis and AD: analysis of data from the US National Alzheimer's Coordinating Center. Neurology 2005, 64(3):494-500.

7. Wollmer MA: Cholesterol-related genes in Alzheimer's disease. Biochim Biophys Acta 2010, 1801(8):762-773.

8. Björkhem I, Leoni V, Meaney S: Genetic connections between neurological disorders and cholesterol metabolism. J Lipid Res 2010, 51(9):2489-2503.

9. Martins IJ, Berger T, Sharman MJ, et al: Cholesterol metabolism and transport in the pathogenesis of Alzheimer's disease. J Neurochem 2009, 111(6):1275-1308.

10. Reitz C, Tang MX, Schupf N, et al: Association of higher levels of highdensity lipoprotein cholesterol in elderly individuals and lower risk of late-onset Alzheimer disease. Arch Neurol 2010, 67(12):1491-1497.

11. Kuo YM, Emmerling MR, Bisgaier CL, Essenburg AD, Lampert HC, Drumm D, Roher AE: Elevated low-density lipoprotein in Alzheimer's disease correlates with brain abeta 1-42 levels. Biochem Biophys Res Commun 1998, 252(3):711-715.

12. Hall K, Murrell J, Ogunniyi A, et al: Cholesterol, APOE genotype, and Alzheimer disease: an epidemiologic study of Nigerian Yoruba. Neurology 2006, 66(2):223-227.

13. Liu HC, Hu CJ, Chang JG, Sung SM, Lee LS, Yuan RY, Leu SJ: Proteomic identification of lower apolipoprotein A-I in Alzheimer's disease. Dement Geriatr Cogn Disord 2006, 21(3):155-161.

14. Anstey KJ, Lipnicki DM, Low LF: Cholesterol as a risk factor for dementia and cognitive decline: a systematic review of prospective studies with meta-analysis. Am J Geriatr Psychiatry 2008, 16(5):343-354.

15. Solomon A, Kivipelto M, Wolozin B, et al: Midlife serum cholesterol and increased risk of Alzheimer's and vascular dementia three decades later. Dement Geriatr Cogn Disord 2009, 28(1):75-80.

16. Beydoun MA, Beason-Held LL, Kitner-Triolo MH, Beydoun HA, Ferrucci L, Resnick SM, Zonderman AB: Statins and serum cholesterol's associations with incident dementia and mild cognitive impairment. J Epidemiol Community Health 2011, 65(11):949-957.

17. Bettermann K, Arnold AM, Williamson J, Rapp S, Sink K, Toole JF, Carlson MC, Yasar S, Dekosky S, Burke GL: Statins, risk of dementia, and cognitive function: secondary analysis of the ginkgo evaluation of memory study. J Stroke Cerebrovasc Dis 2012, 21(6):436-444.

18. Jaya Prasanthi RP, Schommer E, Thomasson S, et al: Regulation of betaamyloid levels in the brain of cholesterol-fed rabbit, a model system for sporadic Alzheimer's disease. Mech Ageing Dev 2008, 129(11):649-655.

19. Thirumangalakudi L, Prakasam A, Zhang R, et al: High cholesterol-induced neuroinflammation and amyloid precursor protein processing correlate with loss of working memory in mice. J Neurochem 2008, 106(1):475-485.

20. Ullrich C, Pirchl M, Humpel C: Hypercholesterolemia in rats impairs the cholinergic system and leads to memory deficits. Mol Cell Neurosci 2010, 45(4):408-417.

21. Ghribi O: Potential mechanisms linking cholesterol to Alzheimer's disease-like pathology in rabbit brain, hippocampal organotypic slices, and skeletal muscle. J Alzheimers Dis 2008, 15(4):673-684

22. Marwarha G, Dasari B, Prasanthi JR, et al: Leptin reduces the accumulation of Abeta and phosphorylated tau induced by 27-hydroxycholesterol in rabbit organotypic slices. J Alzheimers Dis 2010, 19(3):1007-1019.

23. Prasanthi JR, Huls A, Thomasson S, et al: Differential effects of 24hydroxycholesterol and 27-hydroxycholesterol on beta-amyloid precursor protein levels and processing in human neuroblastoma $\mathrm{SH}-$ SY5Y cells. Mol Neurodegener 2009, 6(4):1.

24. Sharma S, Prasanthi RPJ, Schommer E, et al: Hypercholesterolemia-induced Abeta accumulation in rabbit brain is associated with alteration in IGF-1 signaling. Neurobiol Dis 2008, 32(3):426-432.

25. Tsompanidi EM, Brinkmeier MS, Fotiadou EH, Giakoumi SM, Kypreos KE: HDL biogenesis and functions: role of HDL quality and quantity in atherosclerosis. Atherosclerosis 2010, 208(1):3-9.

26. Cavelier C, Lorenzi I, Rohrer L, et al: Lipid efflux by the ATP-binding cassette transporters ABCA1 and ABCG1. Biochim Biophys Acta 2006, 1761(7):655-666.

27. Brooks-Wilson A, Marcil M, Clee SM, et al: Mutations in ABC1 in Tangier disease and familial high-density lipoprotein deficiency. Nat Genet 1999, 22:336-345.

28. Attie AD: ABCA1: at the nexus of cholesterol, HDL and atherosclerosis. Trends Biochem Sci 2007, 32(4):172-179.

29. Frikke-Schmidt R, Nordestgaard BG, Stene MC, et al: Association of loss-offunction mutations in the ABCA1 gene with high-density lipoprotein cholesterol levels and risk of ischemic heart disease. JAMA 2008, 299:2524-2532.

30. Ye D, Lammers B, Zhao Y, et al: ATP-binding cassette transporters A1 and G1, HDL metabolism, cholesterol efflux, and inflammation: important targets for the treatment of atherosclerosis. Curr Drug Targets 2011, 12(5):647-660

31. Akram A, Schmeidler J, Katsel P, et al: Hof and Vahram Haroutunian. Increased expression of cholesterol transporter ABCA1 is highly correlated with severity of dementia in $A D$ hippocampus. Brain Research 2010, 1318:167-177.

32. Koldamova R, Staufenbiel M, Lefterov I: Lack of ABCA1 considerably decreases brain apoE level and increases amyloid deposition in APP23 mice. J Biol Chem 2005, 280(52):43224-43235.

33. Wahrle $S E$, Jiang $H$, Parsadanian $M$, et al: Deletion of abca1 increases A deposition in the PDAPP transgenic mouse model of Alzheimer disease. J Biol Chem 2005, 280(52):43236-43242.

34. Wellington $C L: A B C A 1$, but not $A B C G 1$, modulates brain amyloid deposition in the PDAPP mouse model of Alzheimer's disease. Alzheimer's and Dementia 2008, 4:T151.

35. Wahrle $S E$, Jiang $H$, Parsadanian $M$, et al: Overexpression of $A B C A 1$ reduces amyloid deposition in the PDAPP mouse model of Alzheimer disease. J Clin Investig 2008, 118(2):671-682.

36. Hirsch-Reinshagen V, Maia LF, Burgess BL, et al: The absence of ABCA1 decreases soluble ApoE levels but does not diminish amyloid deposition in two murine models of Alzheimer disease. J Biol Chem 2005, 280:43243-43256.

37. Hirsch-Reinshagen V, Chan JY, Wilkinson A, et al: Physiologically regulated transgenic ABCA1 does not reduce amyloid burden or amyloid-beta peptide levels in vivo. J Lipid Res 2007, 48:914-923.

38. Wollmer MA, Streffer JR, Lutjohann D, et al: ABCA1 modulates CSF cholesterol levels and influences the age at onset of Alzheimer's disease. Neurobiol Aging 2003, 24(3):421-426.

39. Zambon A, Deeb SS, Pauletto P, Crepaldi G, Brunzell JD: Hepatic lipase: a marker for cardiovascular disease risk and response to therapy. Curr Opin Lipidol 2003, 14(2):179-189.

40. Santamarina-Fojo S, Haudenschild C, Amar M: The role of hepatic lipase in lipoprotein metabolism and atherosclerosis. Curr Opin Lipidol 1998, 9(3):211-219.

41. Barter PJ: Hugh sinclair lecture: the regulation and remodelling of HDL by plasma factors. Atheroscler Suppl 2002, 3(4):39-47.

42. Hong SH, Song J, Kim JQ: Genetic variations of the hepatic lipase gene in Korean patients with coronary artery disease. Clin Biochem 2000, 33(4):291-296

43. Soyal SM, Sandhofer A, Hahne P, et al: Cholesteryl ester transfer protein and hepatic lipase gene polymorphisms: Effects on hepatic mRNA levels, plasma lipids and carotid atherosclerosis. Atherosclerosis 2011, 216(2):374-380.

44. Kashani Farid MA, Azizi F, Hedayati M, et al: Association between CETP Taq1B and LIPC -514C/T polymorphisms with the serum lipid levels in a group of Tehran's population: a cross sectional study. Lipids Health Dis 2010, 9:96.

45. Wang $H$, Jiang M, Qiu J: Quantitative assessment of the effect of hepatic lipase gene polymorphism on the risk of coronary heart disease. Arch Med Res 2010, 41(5):383-390. 
46. Cai SJ, Wong DM, Chen SH, Chan L: Structure of the human hepatic triglyceride lipase gene. Biochemistry 1989, 28(23):8966-8971.

47. Perret $B$, Mabile L, Martinez L, et al: Hepatic lipase: structure/function relationship, synthesis, and regulation. J Lipid Res 2002, 43:1163-1169.

48. Tahvanainen E, Syvänne M, Frick M, Murtomäki-Repo S, Antikainen M, Kesäniemi Y, Kauma H, Pasternak A, Taskinen M, Ehnholm C: Association of variation in hepatic lipase activity with promoter variation in the hepatic lipase gene: the LOCAT Study Investigators. J Clin Invest 1998, 101:956-960.

49. Zambon A, Deeb SS, Hokanson JE, Brown BG, Brunzell JD: Common variants in the promoter of the hepatic lipase gene are associated with lower levels of hepatic lipase activity, buoyant LDL, and higher HDL2 cholesterol. Arterioscler Thromb Vasc Biol 1998, 18(11):1723-1729.

50. Wu J, Yin $\mathrm{R}$, Lin $\mathrm{W}$, et al: Hepatic lipase gene $-514 \mathrm{C} / \mathrm{T}$ polymorphism in the Guangxi Hei Yi Zhuang and Han populations. Lipids 2008, 43(8):733-740

51. de Andrade FM, Silveira FR, Arsand M, et al: Association between -250 G/A polymorphism of the hepatic lipase gene promoter and coronary artery disease and HDL-C levels in a Southern Brazilian population. lin Genet 2004, 65(5):390-395.

52. Wei M, Lu YS, Li PP: Association of the hepatic lipase gene $-250 \mathrm{G} / \mathrm{A}$ promoter polymorphism with the susceptibility to type 2 diabetes mellitus combining with coronary heart disease. Zhonghua Yi Xue Yi Chuan Xue Za Zhi 2009, 26(2):219-222.

53. Drayna D, Lawn R: Multiple RFLPs at the human cholesteryl ester transfer protein (CETP) locus. Nucleic Acids Res 1987, 15(11):4698.

54. Katzov H, Chalmers K, Palmgren J, et al: Genetic variants of ABCA1 modify Alzheimer disease risk and quantitative traits related to beta-amyloid metabolism. Hum Mutat 2004, 23(4):358-367.

55. Li Y, Tacey K, Doil $L$, et al: Association of ABCA1 with late-onset Alzheimer's disease is not observed in a case-control study. Neurosci Lett 2004, 366(3):268-271.

56. Sundar PD, Feingold E, Minster RL, et al: Gender-specific association of ATP-binding cassette transporter 1 (ABCA1) polymorphisms with the risk of late-onset Alzheimer's disease. Neurobiol Aging 2007, 28(6):856-862.

57. Wang F, Jia JP: Correlation of cholesterol 24-hydroxylase and ATPbinding cassette transporter A1 polymorphisms with Alzheimer's disease. Zhonghua Yi Xue Za Zhi 2007, 87(9):614-618.

58. Rodríguez-Rodríguez E, Mateo I, Llorca J, et al: Association of genetic variants of $A B C A 1$ with Alzheimer's disease risk. Am J Med Genet $B$ Neuropsychiatr Genet 2007, 144B(7):964-968.

59. Chen DW, Yang JF, Tang Z, et al: Cholesteryl ester transfer protein polymorphism D442G associated with a potential decreased risk for Alzheimer's disease as a modifier for APOE epsilon4 in Chinese. Brain Res 2008, 1187:52-57.

60. Laws SM, Eckart K, Friedrich $P$, et al: No association of lipase $C$ polymorphisms with Alzheimer's disease. Neurobiol Aging 2010, 31(12):2192-2193.

61. Zhu H, Taylor JW, Bennett DA, et al: Lack of association of hepatic lipase polymorphisms with late-onset Alzheimer's disease. Neurobiol Aging 2008, 29(5):793-794

62. Folstein MF, Folstein SE, McHugh PR: Mini-mental state. A practical method for grading the cognitive state of patients for the clinician. J Psychiatr Res 1975, 12(3):189-198.

63. McKhann G, Drachman D, Folstein M, Katzman R, Price D, Stadlan EM: Clinical diagnosis of Alzheimer's disease: report of the NINCDS-ADRDA Work Group under the auspices of Department of Health and Human Services Task Force on Alzheimer's Disease. Neurology 1984, 34(7):939-944

64. Expert Panel on Detection, Evaluation, and Treatment of High Blood Cholesterol in Adults: Executive Summary of The Third Report of The National Cholesterol Education Program (NCEP) Expert Panel on Detection, Evaluation, And Treatment of High Blood Cholesterol In Adults (Adult Treatment Panel III). JAMA 2001, 285(19):2486-2497.

65. Clee SM, Zw inderman $\mathrm{AH}$, Engert JC, et al: Common genetic variation in abca1 is associated with altered lipoprotein levels and a modified risk for coronary artery disease. Circulation 2001, 103:1198-1205.

66. Li M, Yin R, Li Y, et al: Association of LIPC $-250 \mathrm{G}>\mathrm{A}$ polymorphism and several environmental factors with serum lipid levels in the Guangxi Bai Ku Yao and Han Populations. Lipids in Health and Disease 2010, 9:28.
67. Corella D, Sáiz C, Guillén M, Portolés O, Mulet F, González Jl, Ordovás JM: Association of TaqIB polymorphism in the cholesteryl ester transfer protein gene with plasma lipid levels in a healthy Spanish population. Atherosclerosis 2000, 152(2):367-376.

68. Merched A, Xia Y, Visvikis S, Serot JM, Siest G: Decreased high-density lipoprotein cholesterol and serum apolipoprotein Al concentrations are highly correlated with the severity of Alzheimer's disease. Neurobiol Aging 2000, 21(1):27-30.

69. Pani A, Mandas A, Diaz G, et al: Accumulation of neutral lipids in peripheral blood mononuclear cells as a distinctive trait of Alzheimer patients and asymptomatic subjects at risk of disease. BMC Med 2009, 7:66.

70. Reitz C, Tang MX, Luchsinger J, et al: Relation of plasma lipids to Alzheimer disease and vascular dementia. Arch Neurol 2004 61(5):705-714.

71. Mielke MM, Zandi PP, Sjögren M, et al: High total cholesterol levels in late life associated with a reduced risk of dementia. Neurology 2005, 64(10):1689-1695.

72. Hendrie HC, Ogunniyi A, Hall KS, Baiyewu O, Unverzagt FW, Gureje O, Gao S, Evans RM, Ogunseyinde AO, Adeyinka AO, Musick B, Hui SL: Incidence of dementia and Alzheimer disease in 2 communities: Yoruba residing in Ibadan, Nigeria, and African Americans residing in Indianapolis, Indiana. JAMA 2001, 285(6):739-747.

73. Balakrishnan K, Verdile G, Mehta PD, Beilby J, Nolan D, Galvão DA, Newton R, Gandy SE, Martins RN: Plasma Abeta42 correlates positively with increased body fat in healthy individuals. J Alzheimers Dis 2005, 8(3):269-282.

74. Minagawa $\mathrm{H}$, Watanabe $\mathrm{A}$, Akatsu $\mathrm{H}$, et al: Homocysteine, another risk factor for Alzheimer disease, impairs apolipoprotein E3 function. $J$ Biol Chem 2010, 285(49):38382-38388.

75. Li G, Shofer JB, Rhew IC, Kukull WA, Peskind ER, McCormick W, Bowen JD, Schellenberg GD, Crane PK, Breitner JC, Larson EB: Age-varying association between statin use and incident Alzheimer's disease. J Am Geriatr Soc 2010, 58(7):1311-1317.

76. Adunsky A, Chesnin V, Ravona R, et al: Plasma lipid levels in Alzheimer's disease patients treated by Donepezil hydrochloride: a cross-sectional study. Arch Gerontol Geriatr 2004, 38(1):61-68.

77. Lesser GT, Beeri MS, Schmeidler J, et al: Cholesterol and LDL relate to neuritic plaques and to APOE4 presence but not to neurofibrillary tangles. Curr Alzheimer Res 2011, 8(3):303-312.

78. Kölsch H, Lütjohann D, Jessen $F$, et al: Polymorphism in ABCA1 influences CSF 24S-hydroxycholesterol levels but is not a major risk factor of Alzheimer's disease. Int J Mol Med 2006, 17(5):791-794.

79. Frikke-Schmidt R, Nordestgaard BG, Jensen GB, Tybjaerg-Hansen A: Genetic variation in $A B C$ transporter $A 1$ contributes to $H D L$ cholesterol in the general population. J Clin Invest 2004, 114:1343-1353.

80. Donkin JJ, Stukas S, Hirsch-Reinshagen V, et al: ATP-binding cassette transporter $A 1$ mediates the beneficial effects of the liver $X$ receptor agonist GW3965 on object recognition memory and amyloid burden in amyloid precursor protein/presenilin 1 mice. J Biol Chem 2010, 285(44):34144-34154.

81. Lee $J H$, Mayeux R, Mayo D, et al: Fine mapping of $10 q$ and $18 q$ for familial Alzheimer's disease in Caribbean Hispanics. Mol Psychiatry 2004, 9 (11):1042-1051.

82. Ma XY, Liu JP, Song ZY: Associations of the ATP-binding cassette transporter A1 R219K polymorphism with HDL-C level and coronary artery disease risk: a meta-analysis. Atherosclerosis 2011. 215(2):428-434

83. Yvan-Charvet $L$, Wang $N$, Tall AR: Role of HDL, ABCA1, and ABCG1 transporters in cholesterol efflux and immune responses. Arterioscler Thromb Vasc Biol 2010, 30(2):139-143.

84. Soro-Paavonen A, Naukkarinen J, Lee-Rueckert $M$, et al: Common ABCA1 variants, HDL levels, and cellular cholesterol efflux in subjects with familial low HDL. J Lipid Res 2007, 48(6):1409-1416.

85. Cenarro A, Artieda M, Castillo S, et al: A common variant in the ABCA1 gene is associated with a lower risk for premature coronary heart disease in familial hypercholesterolaemia. J Med Genet 2003, 40(3):163-168

86. Jiang Z, Zhou R, Xu C, et al: Genetic variation of the ATP-binding cassette transporter A1 and susceptibility to coronary heart disease. Mol Genet Metab 2011, 103(1):81-88. 
87. Mantaring M, Rhyne J, Ho Hong S, et al: Genotypic variation in ATPbinding cassette transporter-1 (ABCA1) as contributors to the high and low high-density lipoprotein-cholesterol (HDL-C) phenotype. Trans/ Res 2007, 149(4):205-210.

88. Genvigir FD, Soares SA, Hirata MH, et al: Effects of ABCA1 SNPs, including the $\mathrm{C}-105 \mathrm{~T}$ novel variant, on serum lipids of Brazilian individuals. Clin Chim Acta 2008, 389(1-2):79-86.

89. Saleheen $D$, Khanum $S$, Haider $S R$, et al: A novel haplotype in ABCA1 gene effects plasma HDL-C concentration. Int J Cardiol 2007, 115(1):7-13.

90. Frikke-Schmidt R, Nordestgaard BG, Jensen $G B$, et al: Genetic variation in $A B C A 1$ predicts ischemic heart disease in the general population. Arterioscler Thromb Vasc Biol 2008, 28(1):180-186.

91. Kolovou V, Kolovou G, Marvaki A, et al: ATP-binding cassette transporter A1 gene polymorphisms and serum lipid levels in young Greek nurses. Lipids Health Dis 2011, 10:56.

92. Hodoğlugil U, Williamson DW, Huang $Y$, et al: Common polymorphisms of ATP binding cassette transporter A1, including a functional promoter polymorphism, associated with plasma high density lipoprotein cholesterol levels in Turks. Atherosclerosis 2005, 183(2):199-212.

93. Tsai MY, Li N, Sharrett AR, et al: Associations of genetic variants in ATPbinding cassette $A 1$ and cholesteryl ester transfer protein and differences in lipoprotein subclasses in the multi-ethnic study of atherosclerosis. Clin Chem 2009, 55(3):481-488.

94. Zhao SP, Xiao ZJ, Li QZ, et al: Relationship between ATP-binding cassette transporter 1 R219K genetic variation and blood lipids. Zhonghua Yi Xue Za Zhi 2004, 84(17):1421-1425.

95. Abellán R, Mansego ML, Martínez-Hervás S, et al: Association of selected $A B C$ gene family single nucleotide polymorphisms with postprandial lipoproteins: results from the population-based Hortega study. Atherosclerosis 2010, 211(1):203-209.

96. Katzov H, Bennet AM, Höglund K, et al: Quantitative trait loci in ABCA1 modify cerebrospinal fluid amyloid-beta 1-42 and plasma apolipoprotein levels. J Hum Genet 2006, 51(3):171-179.

97. Porchay I, Péan F, Bellili N, et al: ABCA1 single nucleotide polymorphisms on high-density lipoprotein-cholesterol and overweight: the D.E.S.I.R. Study. Obesity (Silver Spring) 2006, 14(11):1874-1879.

98. Huang $Y, W u Y$, Liu $R$, et al: Differential effect of ATP binding cassette transporter A1 R219K and cholesteryl ester transfer protein TaqIB genotypes on HDL-C levels in overweight/obese and non-obese Chinese subjects. Acta Cardiol 2011, 66(2):231-237.

99. Pasdar A, Yadegarfar G, Cumming A, et al: The effect of ABCA1 gene polymorphisms on ischaemic stroke risk and relationship with lipid profile. BMC Med Genet 2007, 8:30.

100. Li J, Wang LF, Li ZQ, et al: Effect of R219K polymorphism of the $A B C A 1$ gene on the lipid-lowering effect of pravastatin in Chinese patients with coronary heart disease. Clin Exp Pharmacol Physiol 2009, 36(5-6):567-570.

101. Thompson A, Di Angelantonio E, Sarwar N, et al: Association of cholesteryl ester transfer protein genotypes with CETP mass and activity, lipid levels, and coronary risk. JAMA 2008, 299(23):2777-2788.

102. Stancáková $A$, Baldaufová $L$, Javorský $M$, et al: Effect of gene polymorphisms on lipoprotein levels in patients with dyslipidemia of metabolic syndrome. Physiol Res 2006, 55(5):483-490.

103. Zhao S, Xie X, Nie S: The $-250 \mathrm{G}->$ A polymorphism in the human hepatic lipase gene promoter affects blood lipids in Chinese. Clin Chim Acta 2006, 365(1-2):149-152.

104. Ko YL, Hsu LA, Hsu KH, et al: The interactive effects of hepatic lipase gene promoter polymorphisms with sex and obesity on high-densitylipoprotein cholesterol levels in Taiwanese-Chinese. Atherosclerosis 2004, 172(1):135-142.

105. Dichek HL, Brecht W, Fan J, et al: Overexpression of hepatic lipase in transgenic mice decreases apolipoprotein B-containing and high density lipoproteins. Evidence that hepatic lipase acts as a ligand for lipoprotein uptake. J Biol Chem 1998, 273(4):1896-1903.

106. Wood KC, Fullerton MD, El-Sohemy A, et al: Interactions between hepatic lipase and apolipoprotein E gene polymorphisms affect serum lipid profiles of healthy Canadian adults. Appl Physiol Nutr Metab 2008, 33 (4):761-768

107. Jansen $H$, Verhoeven AJ, Sijbrands EJ: Hepatic lipase: a pro- or antiatherogenic protein? J Lipid Res 2002, 43(9):1352-1362.
108. Zambon A, Bertocco S, Vitturi N, Polentarutti V, Vianello D, Crepaldi G: Relevance of hepatic lipase to the metabolism of triacylglycerol-rich lipoproteins. Biochem Soc Trans 2003, 31(Pt 5):1070-1074.

109. Guerra R, Wang J, Grundy SM, Cohen JC: A hepatic lipase (LIPC) allele associated with high plasma concentrations of high density lipoprotein cholesterol. Proc Natl Acad Sci U S A 1997, 94(9):4532-4537.

110. Morton RE: Cholesteryl ester transfer protein and its plasma regulator: lipid transfer inhibitor protein. Curr Opin Lipidol 1999, 10(4):321-327.

111. Fiegenbaum M, da Silveira FR, Van der Sand CR, et al: Pharmacogenetic study of apolipoprotein $\mathrm{E}$, cholesteryl ester transfer protein and hepatic lipase genes and simvastatin therapy in Brazilian subjects. Clin Chim Acta 2005, 362(1-2):182-188.

112. Arca M, Montali A, Ombres D, Battiloro E, Campagna F, Ricci G, Verna R: Lack of association of the common TaqlB polymorphism in the cholesteryl ester transfer protein gene with angiographically assessed coronary atherosclerosis. Clin Genet 2001, 60(5):374-380.

113. Chamberlain AM, Folsom AR, Schreiner PJ, et al: Low-density lipoprotein and high-density lipoprotein cholesterol levels in relation to genetic polymorphisms and menopausal status: the Atherosclerosis Risk in Communities (ARIC) Study. Atherosclerosis 2008, 200(2):322-328.

114. Saxena R, Voight BF, Lyssenko V, et al: Genome-wide association analysis identifies loci for type 2 diabetes and triglyceride levels. Science 2007, 316:1331-1336.

115. Isaacs A, Aulchenko YS, Hofman A, et al: Epistatic effect of cholesteryl ester transfer protein and hepatic lipase on serum high-density lipoprotein cholesterol levels. J Clin Endocrinol Metab 2007, 92:2680-2687

116. Kathiresan S, Melander O, Anevski D, et al: Polymorphisms associated with cholesterol and risk of cardiovascular events. N Engl J Med 2008, 358(12):1240-1249.

117. Willer CJ, Sanna S, Jackson AU, et al: Newly identified loci that influence lipid concentrations and risk of coronary artery disease. Nat Genet 2008, 40(2):161-169.

118. Kraus WE, Houmard JA, Duscha BD, Knetzger KJ, Wharton MB, McCartney JS, Bales CW, Henes S, Samsa GP, Otvos JD, Kulkarni KR, Slentz CA: Effects of the amount and intensity of exercise on plasma lipoproteins. N Engl Med 2002, 347(19):1483-1492.

119. Takata M, Inazu A, Katsuda S, et al: CETP (cholesteryl ester transfer protein) promoter $-1337 \mathrm{C}>\mathrm{T}$ polymorphism protects against coronary atherosclerosis in Japanese patients with heterozygous familial hypercholesterolaemia. Clin Sci (Lond) 2006, 11(5):325-331.

120. Yamada T, Kawata M, Arai H, Fukasawa M, Inoue K, Sato T: Astroglial localization of cholesteryl ester transfer protein in normal and Alzheimer's disease brain tissues. Acta Neuropathol 1995, 90(6):633-636.

121. Arias-Vásquez A, Isaacs A, Aulchenko YS, Hofman A, Oostra BA, Breteler M, van Duijn CM: The cholesteryl ester transfer protein (CETP) gene and the risk of Alzheimer's disease. Neurogenetics 2007, 8(3):189-193.

122. Sanders $A E$, Wang $C$, Katz $M$, et al: Association of a functional polymorphism in the cholesteryl ester transfer protein (CETP) gene with memory decline and incidence of dementia. JAMA 2010, 303(2):150-158.

123. Zhu H, Gopalraj RK, Kelly JF, Bennett DA, Estus S: Lack of genetic association of cholesteryl ester transfer protein polymorphisms with late onset Alzheimers disease. Neurosci Lett 2005, 381(1-2):36-41.

124. Qureischie $H$, Heun R, Lütjohann D, et al: CETP polymorphisms influence cholesterol metabolism but not Alzheimer's disease risk. Brain Res 2008, 1232:1-6.

125. Fidani L, Goulas A, Crook R, Petersen RC, Tangalos E, Kotsis A, Hardy J: An association study of the cholesteryl ester transfer protein Taql B polymorphism with late onset Alzheimer's disease. Neurosci Lett 2004, 357(2):152-154.

126. Letenneur L, Gilleron V, Commenges D, Helmer C, Orgogozo JM, Dartigues JF: Are sex and educational level independent predictors of dementia and Alzheimer's disease? Incidence data from the PAQUID project. J Neurol Neurosurg Psychiatry 1999, 66(2):177-183.

127. Stern Y, Gurland B, Tatemichi TK, Tang MX, Wilder D, Mayeux R: Influence of education and occupation on the incidence of Alzheimer's disease. JAMA 1994, 271(13):1004-1010.

128. EClipSE Collaborative M, Brayne C, Ince PG, et al: Education, the brain and dementia: neuroprotection or compensation? Brain 2010, 133(Pt 8):2210-2216. 
129. Reuser M, Willekens FJ, Bonneux L: Higher education delays and shortens cognitive impairment: a multistate life table analysis of the US Health and Retirement Study. Eur J Epidemiol 2011, 26(5):395-403.

130. Cobb JL, Wolf PA, Au R, et al: The effect of education on the incidence of dementia and Alzheimer's disease in the Framingham Study. Neurology 1995, 45(9):1707-1712.

doi:10.1186/1476-511X-11-163

Cite this article as: Xiao et al:: Association studies of several cholesterolrelated genes (ABCA1, CETP and LIPC) with serum lipids and risk of

Alzheimer's disease. Lipids in Health and Disease 2012 11:163.

\section{Submit your next manuscript to BioMed Central and take full advantage of:}

- Convenient online submission

- Thorough peer review

- No space constraints or color figure charges

- Immediate publication on acceptance

- Inclusion in PubMed, CAS, Scopus and Google Scholar

- Research which is freely available for redistribution 